\title{
PENGARUH ROA DAN ROE TERHADAP HARGA SAHAM PADA INDEKS LQ 45 DI BURSA EFEK INDONESIA (BEI) PERIODE 2015-2018
}

\author{
Ani Pujiati ${ }^{(1)}$, Ade Sandra Dewi(2) \\ Fakultas Ekonomi Universitas Sang Bumi Ruwa Jurai \\ anipujiati@gmail.com,42.adedewi@gmail.com
}

\begin{abstract}
Abstrak. Eksternal bagi dunia usaha. Investasi dilakukan dengan bertujuan memperoleh keuntungan sesuai dengan yang diharapkan. Oleh karena itu, untuk mengatasi tujuan tersebut perusahaan harus meningkatkan nilai perusahaan. Penelitian bertujuan untuk mengetahui pengaruh Return on Asset (ROA) dan Return on Equity (ROE) terhadap harga saham pada perusahaan tergabung LQ45 yang terdapat di Bursa Efek Indonesia (BEI). penelitian ini menggunakan penelitian kuantitatif dengan teknik analisis regresi linier berganda. Sumber data menggunakan data skunder. Berdasarkan hasil pengolahan data yang dilakukan dengan mengunakan SPSS versi 20 diperoleh bahwa Return on Asset (ROA) dan Return on Equity (ROE) berpengaruh positif signifikan terhdap harga saham artinya semakin Return on Asset (ROA) dan Return on Equity (ROE) maka harga saham akan semakin tinggi yang pada akhirnya akan menaikan nilai perusahaan.
\end{abstract}

Kata kunci: ROA,ROE, harga saham.

\section{PENDAHULUAN}

Pasar Modal merupakan sarana pembentuk modal dan akumulasi dana yang diarahkan, untuk meningkat partisipasi masyarakat dalam pengarahan dana guna menunjang pembiayaan pembangunan nasional(Ahmad, 2017). Kegiatan Pasar Modal di Indonesia diatur dalam UU No. 8 Tahun 1995 tentang Pasar Modal (UUPM) (Sutedi;2011). Pasar Modal di Indonesia mempunyai objek investasi yang diperdagangkan berupa surat-surat berharga seperti saham, obligasi, dan sertifikat PT Danareksa(Ahmad, 2017).Bursa efek atau stock exchange adalah suatu sistem yang terorganisasi yang mempertemukan penjual dan pembeli efek(Andri, 2014)

Penetrasi pasar modal di Indonesia masih terbilang kecil masih sebesar 3,7\% (OJK;2013). Namun saat pandemi ini tahun 2020 OJK menilai kondisi Pasar Modal masih stabil dan positif ditengah perkembangan iklim sektor keuangan.
Menurut Theodora, nilai transaksi harian nasabah retail tahun 2020 meningkat sekitar $70 \%$ secara tahunan dibanding dengan periode yang sama tahun lalu dimana peningkatan saat pandemi karena suku bunga rendah (cnbcindonesia.com;2020).

Saham yang diperdagangkan di pasar modal memiliki harga saham merupakan tanda kepemilikan seseorang atau badan dalam suatu perusahaan yang merupakan refleksi dari keputusan investasi, pendanaan, dan pengelolaan aset. Harga saham saham ditentukan oleh permintaan dan penawaran pasar. Pergerakan harga suatu saham dalam jangka pendek tidak dapat diterka secara pasti. Harga saham dipengaruhi oleh faktor external dan faktor internal perusahaan. Faktor internal yang mempengaruhi harga saham adalah fundamental perusahaan, kebijakan perusahaan, dan proyeksi kinerja perusahaan pada masa mendatang(Brigham, 2014) bisa dilihat dari laporan keuangan perusahaan, misal pada profitabilitasnya. Menurut Paradiba \& Nanggolan (2015) 
bahwa laba bersih operasi berpengaruh signifikan terhadap harga saham. Dapat dikatakan profitabilitas dapat mempengaruhi harga saham. Calon investor menilai perusahaan dengan profitabilitas yang baik akan memberikan dividen yang baik sehingga akan meningkatkan harga saham. Profitabilitas yang dipakai dalam melihat pengarunya terhadap harga saham adalah Return on Assets (ROA) dan Return on Equity (ROE).

Return On Assets (ROA), yaitu yang menunjukkan hasil atas jumlah aktivas yang digunakan oleh perusahaan(Kasmir, 2014). Perusahaan dengan tingkat return on assets yang tinggi, umumnya menggunakan hutang dalam jumlah yang relatif sedikit. Hal ini disebabkan dengan return on assets yang tinggi tersebut, memungkinkan bagi perusahaan melakukan permodalan dengan laba ditahan saja. Akan tetapi tidak itu saja, asumsi yang lain mengatakan dengan return on assets yang tinggi, berarti bahwa laba bersih yang dimiliki perusahaan tinggi, maka apabila perusahaan menggunakan hutang yang besar tidak akan berpengaruh terhadap struktur modal, karena kemampuan perusahaan dalam membayar bunga tetap juga tinggi. Tingkat pengembalian yang tinggi memungkinkan untuk membiayai sebagian besar kebutuhan pendanaan dengan dana yang dihasilkan.

ROE mampu mengukur kemampuan perusahaan memperoleh laba yang tersedia bagi pemegang saham perusahaan (Sartono:2012). Rasio ini juga dipengaruhi oleh besar kecilnya utang perusahaan, apabila proporsi utang besar maka rasio ini akan besar. ROE sangat bergantung pada besar kecilnya perusahaan. Pada perusahaan kecil memiliki modal yang kecil sehingga ROE nya kecil.

ROE sangat menarik bagi pemegang maupun calon pemegang saham. ROE yang tinggi akan menaikan nilai perusahaan, sehingga menjadi daya tarik bagi investor untuk menanamkan modalnya di perusahaan tersebut.

Suatu perusahaan dapat menjual hak kepemilikannya dalam bentuk saham (Jogiyanto Hartono;2013). Harga saham adalah harga saham di bursa saham pada saat tertentu yang ditentukan oleh pelaku pasar. Harga saham ditentukan oleh permintaan dan penawaran saham dipasar modal. Faktor-faktor yang mempengaruhi kenaikan harga saham (Oktavia, Irene dan Genjar, Kevin;2019): 1.Kinerja perusahaan yang tercermin dari Laporan keuangan dan rasio keuangan; 2. Kebijakan pemerintah; 3. asimetri informasi kurs; 4.pajak; 5. Anomali cuaca; 6. Isu-isu perusahaan seperti penggabungan usaha, akuisis, peleburan usaha, pemecahan saham, pembagian dividen saham, dan tata kelola perusahaan.

Harga saham berasal dari penawaran dan permintaan saham perusahaan di pasar modal. Salah satu indikasi saham yang diminati oleh investor dan calon investor adalah profitabilitasnya baik. Karena dengan laba yang baik, investor ataupun calon investor mengharapkan mendapatkan pembagian laba atau sering disebut dividen.

Keuntungan lain yang diharapkan oleh investor maupun calon investor adalah adanya selisih untung dari harga beli dan harga jual yang sering disebut capital gain. Capital gain terjadi bila semakin banyak yang melakukan permintaan terhadap saham pada suatu perusahaan. Permintaan saham pada suatu perusahaan akan naik salah satunya karena profitabilitas mengalami peningkatan. Sehingga dapat dikatakan bahwa profitabilitas akan mempengaruhi harga sham. Profitabilita pada penelitian ini mengacu pada Return on Aseets (ROA) dan Return on Equity (ROE).

Menurut Satria dan Haryani ROE berpengaruh positif dan signifikan terhadap harga saham(Satria \& Haryani, 2015). (Pratama \& Teguh, 2014) mengungkapkan terdapat pengaruh yang signifikan dari Return On Equity terhadap harga saham 
namun dari hasil Beta menunjukkan nilai negatif, yang berarti bahwa variasi perubahan nilai variabel independen tidak dapat menjelaskan variabel dependen.

Pada penelitian Citra dan Nurwiyanta ROE berpengaruh signifikan terhadap harga saham(Citra \& Nurwiyanta, 2014). Penelitian Widya dan Abundanti (2018) dan penelitian Ircham (Ircham et al., 2014) menunjukkan bahwa $R O E$ berpengaruh negatif terhadap harga saham.

Pada penelitian Santy (Santy, 2017), penelitian Takarini dan Hendrarini (2011), dan penelitian Sutapa (2018) ROE tidak berpengaruh terhadap harga saham.

Hasil penelitian Anisma (2012) dan Santy (2017) ROA mempengaruhi harga saham. Citra dan Nurwiyanta (2014) mengungkapkan ROA berpengaruh signifikan terhadap harga saham.

Dengan demikian berdasarkan uraian diatas peneliti teratarik untuk peneliti tentang Pengaruh ROA dan ROE Terhadap Harga Saham pada Perusahaan LQ45 di Bursa Efek Indonesia Periode 2015-2018.

\section{METODE PENELITIAN}

\section{Jenis Penelitian}

Berdasarkan permasalahan dan tujuan penelitian maka penelitian ini menggunakan penelitian kuantitatif yang sering disebut metode tradisional. Penelitian kuantitatif didasari oleh filsafat positivisme yang menekankan fenomena-fenomena objektif dan dikaji secara kuantitatif (Nana;2012). Objektivitas dalam penelitian kuantitatif dengan menggunakan angka-angka, pengolahan statistik, struktur dan percobaan terkontrol.

\section{Lokasi Penelitian}

Penelitian ini dilakukan pada website Pasar modal Bursa Efek Indonesia (BEI) (www.idx.co.id). Pasar modal merupakan pasar untuk berbagai instrumen keuangan jangka panjang yang bisa diperjualbelikan.

\section{Sumber Data}

Penelitian ini menggunakan data sekunder. Pengambilan sampel menggunakan teknik purposive sampling. Purposive sampling adalah menentukan sampel dengan pertimbangan tertentu yang dipandang dapat memberikan data secara maksimal. Data tersebut adalah harga penutupan saham tahunan, Return on Asset (ROA) dan Return on Equity (ROE) tahunan periode 2015-2018.

\section{Populasi}

Penelitian yang bersifat penelitian populasi memiliki arti seluruh subjek di dalam wilayah penelitian dijadikan subjek penelitian. Populasi adalah kelompok di mana seseorang peneliti akan memperoleh hasil penelitian yang disamaratakan (digeneralisasikan)

Pengertian populasi yang lain adalah jumlah keseluruhan unit analisis, yaitu obyek yang akan diteliti.

\section{Sampel}

Penelitian yang bersifat penelitian sampel hanya memilih sebagian dari subjek penelitian dan mengganggapnya mewakili keseluruhan. Pertimbangan yang diambil untuk tidak meneliti seluruh subjek karena yang diambil yang sesuai kriteria saja, yaitu perusahaan masuk ke daftar tetap LQ45 secara terus menerus dari tahun 2015-2018 dan perusahaan bukan termasuk perusahaan keuangan. Indeks ini diambil dari dari 45 saham-saham yang paling aktif diperdagangkan.Pengambilan sebagian dari populasi sudah dapat mencerminkan sifat dari populasinya Berdasarkan teknik pengambilan sampel tersebut, diperoleh jumlah sampel (n) dari data time series tahunan selama periode tahun 2015-2018, yaitu sebanyak 24 perusahaan. 


\section{Variabel dan Pengukuran}

\section{Return on Assets (ROA)}

Return on Assets adalah rasio profitabilitas yang mengukur kemampuan perusahaan menghasilkan laba dari penggunaan seluruh sumber daya atau asset yang dimilikinya . Data yang digunakan dalam penelitian ini guna mengetahui Return on Assets adalah data laporan keuangan perusahaan tahunan yang dikeluarkan oleh Bursa Efek Indonesia periode tahun 2015-2018 dalam satuan persen $(\%)$.

\section{Return on Equity (ROE)}

Return on Equity digunakan untuk mengukur kemampuan suatu badan usaha dalam menghasilkan laba dengan bermodalkan ekuitas yang sudah diinvestasikan oleh pemegang saham. Data yang digunakan dalam penelitian ini guna mengetahui Return on Equity adalah data laporan keuangan perusahaan tahunan yang dikeluarkan oleh Bursa Efek Indonesia periode tahun 2015 -2018 dalam satuan persen $(\%)$.

\section{Harga saham}

oleh kekuatan pasar, dalam arti tergantung kekuatan permintaan dan penawaran saham itu sendiri. Data harga saham yang digunakan dalam penelitian ini dikeluarkan oleh Bursa Efek Indonesia yang diambil di periode tahun $2015-2018$.

\section{Teknik Pengumpulan Data}

Metode yang digunakan dalam penelitian adalah mengumpulkan data dalam penelitian ini menggunakan teknik dokumentasi. Dokumentasi dari asal kata dokumen, yang artinya barang-barang tertulis (Arikunto ; 2010).
Teknik ini dilakukan dengan melihat data-data sekunder yang telah di sediakan oleh Bursa Efek Indonesia yang meliputi data Return on Assets, Return on Equity dan harga saham

\section{Teknik Analisis Data}

Analisis regresi linier berganda (Multi Regression Linier Analysis) digunakan untuk mengetahui pengaruh dari variabel dependent (variabel yang dipengaruhi), sekaligus digunakan untuk melihat pengaruh terhadap harga saham. Wooldridge menyatakan bahwa analisis regresi berganda mempunyai kemampuan untuk analisis cateris paribus karena secara eksplisit mengontrol banyak faktor secara simultan yang berpengaruh terhadap variabel dependen (Latan;2014). Analisis regresi linier berganda menghasilkan sebuah persamaan regresi yang dapat digunakan dalam prediksi. Secara matematis dapat dituliskan sebagai berikut:

$$
\mathrm{Y}=\alpha+\beta \mathrm{X} 1+\beta \mathrm{X} 2+\mathrm{e}
$$

Dimana :

Y merupakan variabel dependen

$\mathrm{X}$ merupakan variabel independen

$\alpha$ merupakan intercept

ß merupakan slope

e merupakan error term

\section{Pengujian Asumsi Klasik}

Pengujian asumsi klasik untuk memastikan bahwa model yang diperoleh benar- benar memenuhi asumsi dasar dalam analisis regresi linear berganda yang meliputi asumsi normalitas, tidak terjadi autokorelasi, tidak terjadi heteroskedastisitas dan tidak terjadi multikolinearitas.

\section{Pengujian Hipotesis}

\section{a. Koefisien Determinasi (R2)}

Analisis korelasi terdapat suatu angka yang disebut dengan koefisien determinasi yang sering disebut dengan 
koefisien penentu. Bila semua variabel diregresikan secara bersama-sama terhadap variabel terikat dengan maksud menjelaskan varians di dalamnya, korelasi individual jatuh ke dalam apa yang disebut multipel $r$, Rsquare atau sering disebut $\mathrm{R}^{2}$, adalah jumlah varians yang dijelaskan dalam

\section{b. Uji Simultan (Uji F)}

Uji $F$ digunakan untuk menguji pengaruh beberapa variabel secara bersama-sama terhadap variabel yang lain dengan taraf signifikan 5\%. Analisis varians (ANOVA) membantu menguji perbedaan rata-rata yang signifikan di antara lebih dari dua kelompok pada variabel terikat yang berskala interval atau rasio ${ }^{1}$. Hasil ANOVA menunjukkan apakah ratarata dari berbagai kelompok secara signifikan berbeda satu sama lain, seperti yang ditunjukkan oleh statistik F. Statistik F menunjukkan apakah dua varians sampel berbeda satu sama lain atau dari populasi yang sama.

\section{c. Uji Parsial (Uji t)}

Uji $t$ dalam penelitian ini digunakan untuk menguji signifikansi pengaruh variabel independen secara sendiri-sendiri (parsial) terhadap variabel dependen. Dalam uji $t$ memasukan rata-rata dan standar deviasi dari dua kelompok pada variabel dan menguji apakah perbedaan numerikal dalam rata-rata berbeda secara signifikan dari 0 (nol) sebagaimana didalilkan dalam hipotesa nol (Uma Sekaran;2006).

\section{HASIL DAN PEMBAHASAN}

Model regresi linear berganda digunakan untuk menghitung besarnya pengaruh antara variabel bebas, yaitu profitabilitas yang terdiri dari Return on Assets (ROA) (X1) dan Return on Equity (ROA) (X2), terhadap variabel terikat yaitu harga saham (Y). Secara umum rumus persamaan regresi linier berganda adalah $\mathrm{Y}=$ a $+\mathrm{bX} 1+\mathrm{bX} 1+\mathrm{e}$. Hasil perhitungan koefisien regresi dengan menggunakan program SPSS 20.0 didapat model regresi sebagai berikut:

Tabel 1. Hasil Model Regresi Linear Berganda

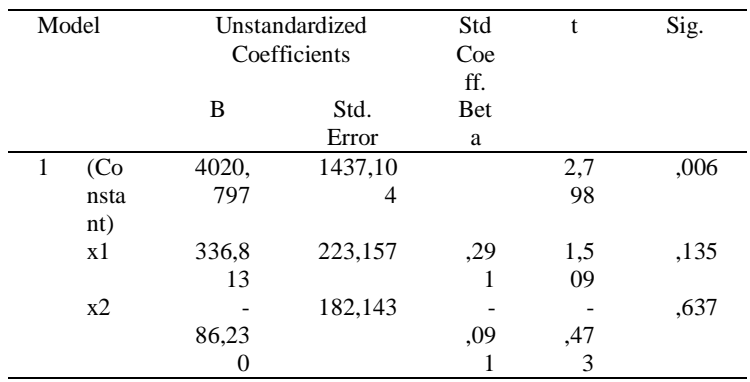

Coefficients $^{\mathrm{a}}$

$\mathrm{a}=$ angka konstan dari unstandardized coefficients. Dalam kasus ini nilainya sebesar 4020,797 Angka ini merupakan angka konstan yang mempunyai arti bahwa jika tidak ada Return on Assets (X1) dan Return on Equity (X2) maka nilai harga saham (Y) adalah sebesar 4020,797

$\mathrm{b}_{1}=$ angka koefisien regresi. Nilainya sebesar 336,813 Angka ini mengandung artibahwa setiap pertambahan $1 \%$ ROA (X1) maka harga saham (Y) akan meningkat 336,813 .

$\mathrm{b}_{2}=$ angka koefisien regresi. Nilainya sebesar -86,230 Angka ini mengandung arti bahwa setiap pertambahan $1 \%$ ROE (X2), maka harga saham (Y) akan meningkat $-86,230$. 
Nilai koefisien regresi bernilai positif dan negatif maka dengan demikian dapat dikatakan bahwa ROA (X1) berpengaruh positif terhadap harga saham (Price) (Y). Sedangkan ROE (X2) berpengaruh negatif terhadap harga saham (Price) (Y).Sehingga persamaan regresinya adalah $\mathrm{Y}=4020,797+336,813 \mathrm{X} 1-86,230$ $\mathrm{X} 2+\mathrm{e}$.

\section{Uji Hipotesis dalam Analisis Regresi Linier Sederhana}

Uji hipotesis atau uji pengaruh berfungsi untuk mengetahui apakah koefisien regresi tersebut signifikan atau tidak. Hipotesa dalam penelitian ini adalah : $\mathrm{H} 0$ = Tidak ada pengaruh ROA dan ROE $(\mathrm{X} 1 \& \mathrm{X} 2)$ terhadap harga saham (Y).

$\mathrm{H} 1$ = Ada pengaruh ROA dan ROE (X1\&X2) terhadap harga saham (Y).

Signifikan atau tidak koefisien regresi tersebut, variabel $\mathrm{X}$ berpengaruh terhadap variabel $\mathrm{Y}$, dapat dilakukan dengan membandingan nilai signifikansi (Sig.) dengan probabilitas 0,05 atau dengan cara membandingan nilai t hitung dengan $\mathrm{t}$ tabel.

Perlunya dilakukan uji hipotesis membandingkan nilai Sig. Dengan 0,05. Pengambilan keputusan dalam analisis regresi berdasar nilai signifikansi (Sig.) hasil output SPSS adalah :

1. Jika nilai signifikansi (Sig.) lebih kecil < dari probabilitas 0,05 mengandung arti bahwa ada pengaruh ROA dan ROE (X1 dan X2) terhadap harga saham (Y).

2. Apabila nilai signifikansi (Sig.) lebih besar > dari probabilitas 0,05 mengandung arti bahwa tidak ada pengaruh ROA dan ROE (X1 dan X2) terhadap harga saham $(\mathrm{Y})$.

3. Penelitian ini memiliki nilai signifikansi (Sig.) 0,006. Dimana nilai $0,006<0,05$ yang memiliki arti bahwa ada pengaruh
ROA dan ROE (X1 dan X2) terhadap harga saham $(Y)$.

Berdasarkan tabel coefficients terdapat nilai t hitung sebesar 2,798 Sedangkan nilai $\mathrm{t}$ tabel dirumuskan Nilai a/2 $=0,05 / 2=$ 0,025 . Derajat kebebasan $(\mathrm{df})=\mathrm{n}-2=92$ $2=90$. Nilai $0,025: 90$ pada tabel $\mathrm{t}$ maka didapat nilai t tabel sebesar 1,98667. Karena nilai t hitung 2,798 lebih besar dari > 1,98667, maka disimpulkan bahwa Ho ditolak dan $\mathrm{H} 1$ diterima, yang berarti bahwa " Ada pengaruh ROA dan ROE (X1 dan X2) terhadap harga sham (Y).

\section{Pengaruh Variabel X terhadap Variabel}

\section{$\mathbf{Y}$}

Besarnya pengaruh ROA dan ROE (X1 \& X2) terhadap harga saham (Y) dalam analisis regresi linier berganda dapat diketahui dari nila $\mathrm{R}$ Square atau R2 pada tabel model summary.

Tabel 2. Koefisien Korelasi dan Determinasi

\begin{tabular}{ccccc}
\multicolumn{5}{c}{ Model Summary $^{\mathbf{b}}$} \\
\hline Model & $\mathrm{R}$ & $\mathrm{R}$ & Adjusted \\
& & $\begin{array}{c}\text { Squar } \\
\mathrm{e}\end{array}$ & $\begin{array}{c}\text { Std. Error } \\
\text { of the } \\
\text { Estimate }\end{array}$ \\
\hline 1 & $\begin{array}{r}\text { 219 } \\
\text { a }\end{array}$ &, 048 &, 027 & 4488,308 \\
\hline
\end{tabular}

a. Predictors: (Constant), $x 2, x 1$

b. Dependent Variable: y

Pada Tabel 2 terdapat nilai $\mathrm{R}$ Square 0,048. Nilai ini mengartikan bahwa pengaruh ROA dan ROE (X1 dan X2) terhadap harga saham (Y) adalah sebesar $4,8 \%$, sedangkan $95,2 \%$ harga saham dipengaruhi oleh variabel lain yang tidak diteliti. 


\section{Hasil Uji Simultan (Uji F)}

Berdasarkan penelitian didapatkan hasil uji F sebagai berikut :

Tabel 3. Hasil Uji Simultan (Uji F)

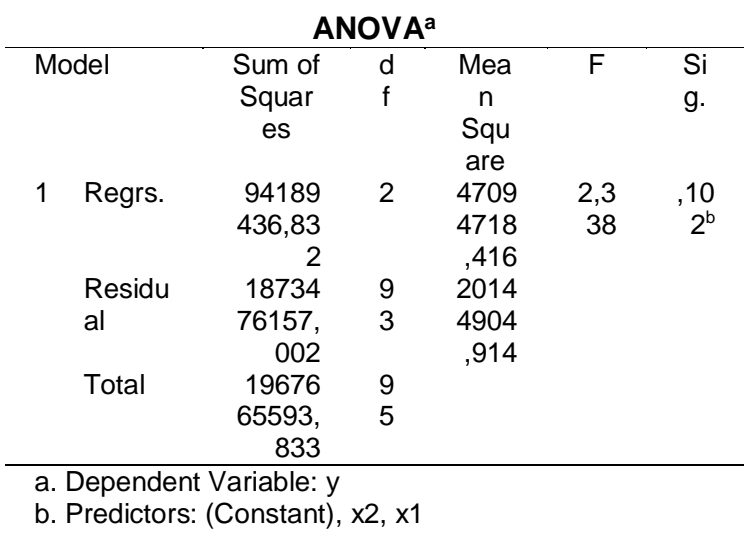

ANOVA untuk menjelaskan apakah ada pengaruh yang nyata (signifikansi) variabel ROA dan ROE (X1 \& X2) terhadap variabel harga saham (Y). Melihat output $F$ hitung $=2,338$ dengan tingkat signifikansi atau probabilitas $0,102>0,05$, maka model regresi dapat dipakai untuk memprediksi harga saham.

\section{KESIMPULAN}

Berdasarkan hasil analisis dan pengujian data yang dilakukan secara statistik, dapat diperoleh kesimpulan bahwa hasil dari penelitian ini menunjukkan bahwa ROA dan ROE berpengaruh terhadap harga saham di Bursa Efek Indonesia dengan pengaruh sebesar $4,8 \%$.

Perlunya dilakukan penelitian faktor-faktor lain yang mempengaruhi harga saham antara lain kinerja laporan keuangan dan rasio-rasio keuangan, kebijakan pemerintah, asimetri informasi kurs, pajak, anomali saham, pembagian dividen saham, dan tata kelola perusahaan.

\section{UCAPAN TERIMAKASIH}

Dalam penyusunan penelitian ini tidak terlepas dukungan dari berbagai pihak. Peneliti mengucapkan terimakasih kepada semua pihak yang membantu. Pada kesempatan ini penulis menyampaikan rasa terima kasih kepada Yayasan dan Pimpinan Rektorat Universitas Sang Bumi Ruwa Jurai. Ucapan terimaksih juga terhadap penyelenggara Jurnal Manajemen Mandiri Saburai yang telah memfasilitasi pengadaan penelitian ini.

\section{DAFTAR PUSTAKA}

Ahmad, K. (2017). Dasar-Dasar Manajemen Investasi Dan Portofolio. (Edisi revisi). Rineka Cipta.

Andri, S. (2014). Masa Depan Pasar Modal Syariah Di Indonesia. Kencana.

Anisma, Yuneita. (2012). Faktor-Faktor Yang Mempengaruhi Harga Saham Perusahaan Perbankan yang Listing di Bursa Efek Indonesia (BEI).Jurnal Sosial Ekonomi Pembangunan. Universitas Riau.Tahun II No.5.Maret 2012.

Brigham, E. F. dan J. F. H. (2014). Dasardasar Manajemen Keuangan. Salemba Empat.

Citra, F. F., \& Nurwiyanta. (2014). Pengaruh Return On Equity (ROE), return On Assets (ROA), Dan Net Profit Margin (NPM) Terhadap Harga Saham Pada Sektor Real estate And Property Di Bursa Efek Indonesia Periode 2008-2011. Jurnal Bisnis Dan Ekonomi, Vol. 5 No. 1, 19-30. 
Ircham, M., Ragil, S., \& Saifi, M. (2014).

Pengaruh Struktur Modal Dan

Profitabilitas Terhadap Harga Saham

(Studi pada Perusahaan Makanan

dan Minuman yang terdaftar di Bursa

Efek Indonesia Tahun 2009-2012).

Jurnal Administrasi Bisnis (JAB), Vol. 11 No. 1.

Kasmir. (2014). Analisis Laporan Keuangan (Edisi Satu Cetakan ketujuh). Raja Grafindo Persada.

Pratama, A., \& Teguh, E. (2014). Pengaruh Curren Ratio, Debt To Equity Ratio, Return On Equity, Net Profit Margin Dan Erning Pershare Terhadap Harga Saham (Study Kasus Pada Perusahaan Manufaktur Yang Terdaftar di Bursa Efek Indonesia Periode 2008-2011). Jurnal Akuntansi Universitas Sarjanawiyata Tamansiswa, Vol. 2 No. 1.

Santy, V. A. D. (2017). Pengaruah ROA, ROE, Dan EPS Terhadap Harga Saham PT. Garuda Indonesia Tbk. Jurnal Ilmu Dan Riset Manajemen. Surabaya: Sekolah Tinggi Ilmu Ekonomi Indonesia (STIESIA), Volume 6, Nomor 9.

Satria, I., \& Haryani, I. (2015). Pengaruh Kinerja Keuangan Terhadap Harga Saham 10 Bank Terkemuka Di Indonesia. Jurnal Akutansi Universitas Pancasila, Vol. XIX. No.02. 